\title{
Association of canopy temperature depression with yield and morphological traits of spring soft wheat under Siberian conditions
}

\author{
S.B. Lepekhov ${ }^{1}$, L.P. Khlebova ${ }^{2}$ \\ ${ }^{1}$ Federal Altai Scientific Centre of Agro-BioTechnologies, Barnaul, Russia \\ ${ }^{2}$ Altai State University, 61 Lenina prospect, Barnaul, 656049, Russia. \\ E-mail: sergei.lepehov@yandex.ru, hlebova61@mail.ru
}

Received: 14.08.2019. Accepted: 26.09.2019

\begin{abstract}
The method of infrared thermometry is widely used in the world to diagnose drought tolerance of crops. However, in Russia the measurement of Canopy temperature depression (CTD) has not yet been carried out. The aim of the study was to measure CTD and consider the possibility of using this trait to assess spring soft wheat varieties when growing in the Altai Territory (SouthWestern Siberia of Russia). The studies were conducted in 2017 and 2018 using 36 varieties of spring soft wheat in the vegetative stage and 14 varieties in the grain filling stage, respectively. Significant differences between the varieties for CTD values in both years of the study were established. There was no reliable correlation between CTD and most of agronomic traits of the studied genotypes. CTD also did not significantly correlate with grain yields in neither 2017 nor 2018 ( $r=0.31 ; r=-0.14$, respectively). However, we found a reliable correlation of the trait with the plant height in $2018(r=0.83)$. This may explain the wide distribution of tall varieties in Siberia. If drought occurs before heading, when the plants are oppressed and do not close the canopy, the use of infrared thermometry is difficult throughout the growing season, since the measurement error increases significantly. In Siberia, this method is suitable only in the conditions of mild droughts or when using the steam precursor in wheat cultivation.
\end{abstract}

Key words: Canopy Temperature (CT); Canopy Temperature Depression (CTD); Spring soft wheat; Grain yield; Plant height; Drought stress

\section{Introduction}

Spring soft wheat is the most common crop in the Altai Territory of Russia, where it is grown in all seven soil-climatic zones on a total area of 2.4-2.5 million ha. More than half of the sown area of soft wheat is located in the Kulunda and Aleysk-Rubtsovsk Steppe Zones, where the main limiting factors in the formation of high wheat yields are lack of available soil moisture, severe temperature conditions during the formation of reproductive organs. Drought is the most significant stressor leading to lower yields (Lepekhov and Korobeynikov, 2013; Lepekhov and Khlebova, 2018). During the period from 2009 to 2019, in the Altai Territory of Russia, drought of various duration and intensity occurred seven times (2010, 2011, 2012, 2013, 2014, 2015, 2019). The most severe drought occurred in 2012, when the yield of spring soft wheat fell to $0.3 \mathrm{t} / \mathrm{ha}$. Breeding drought tolerant varieties is one of the ways to resist drought.

At the present stage of breeding, it is not enough to talk about drought tolerance in general; more accurate differentiation of genotypes is necessary depending on the hydrothermal conditions of individual climatic zones and subzones (Kumakov, 1986). Winslow and Smirnoff (1984) recommend the use of diagnostic methods for drought tolerance differentially, depending on the severity of the drought. So, for conditions of moderate drought, a method of infrared thermometry is proposed. When hydration is maintained through water expenditure, the plant is known to be characterized by a lower canopy temperature (Araus et al., 2002). In situations where water is available in deep soil profiles, the ability to extract it under water-limited conditions has been identified as the principal mechanism for drought adaptation as shown by a robust association of canopy temperature with wheat yields (Olivares-Villegas et al., 2007). In conditions of more severe drought, intensely transpiring samples are no longer promising because of the danger of burnout and more preferably forms that save moisture. They are proposed to be diagnosed by the speed of wilting of cut leaves.

Canopy temperature depression (CTD) is the difference between air $\left(T_{a}\right)$ and canopy $\left(T_{c}\right)$ temperatures and it is positive when the canopy is cooler than the air:

$$
\mathrm{CTD}=\mathrm{T}_{\mathrm{a}}-\mathrm{T}_{\mathrm{c}} \text {. }
$$

Under hot, dry, irrigated conditions in Mexico, a significant correlation between CTD and yield was demonstrated which was robust with respect to crop stage, time of day, and crop irrigation status (Amani et al., 1996). Under drought, canopy temperature (CT) was the most drought-adaptive trait contributing to a higher performance, highly heritable and consistently associated with yield phenotypically and genetically (Olivares-Villegas et al., 2007). Data from RILs, as well as from 60 advanced lines grown at several international locations, indicated CTD to be a powerful and robust selection criterion for heat tolerance. Canopy temperature depression can be measured quickly and easily on experimental wheat plots with an infrared thermometer (Reynolds et al., 1998). Therefore, this feature is not only as useful selection tools in breeding but as valuable screens for high productive phenotyping mapping populations (Montes et al., 2007). The QTLs for canopy temperature in the vegetative stage were identified on linkage groups 1B-a, 2B-a, 3B-b, and 7A-a as exclusively related to stress environments and on 4A-a as robust across environments. Four QTLs for canopy temperature in the grain filling stage (three stress and one robust QTL) were co-located with four stress QTLs for canopy temperature in the vegetative stage. The QTLs identified at 3B-b and 5A-a were robust, while at 1B-a, 2B-a, and 7A-a, the QTLs were specific to stress environments (Pinto et al., 2010). 
In Siberia and Northern Kazakhstan, drought usually occurs before heading (Morgounov and Trethowan, 2008), and the second half of summer is characterized by sufficient or excessive rainfall. In this regard, the methods used to assess drought tolerance in regions with terminal and spring-summer drought may differ. In some years, drought may not occur at all, therefore, it is important to search for criteria that in such conditions will allow drought tolerant varieties to be distinguished. In the Russian scientific literature, there is insufficient information on the use of the infrared thermometry method (Bala and Sikder, 2018). We are not aware of cases when this method was used in breeding in Russia. In this regard, the aim of the study was to consider the possibility of using CTD to assess spring soft wheat varieties when growing in the Altai Territory, located in the south of Western Siberia of the Russian Federation.

\section{Materials and Methods}

The study was conducted in 2017 and 2018 on the experimental field of the Federal Altai Scientific Centre of Agro-BioTechnologies, Barnaul, the Altai Territory, Russia. In 2017, 36 varieties were studied (Saratovskaya 29, Saratovskaya 68, Saratovskaya 70, Saratovskaya 72, Saratovskaya 73, Saratovskaya 74, Saratovskaya 75, Voevoda, Kinel'skaya Otrada, Kinel'skaya Krasa, Kinel'skaya Yubilejnaya, Tulajkovskaya 110, Tulajkovskaya Zolotistaya, Tulajkovskaya Nadezhda, Ershovskaya 34, Sigma, Sigma 2, Melodiya, Uralosibirskaya, Serebristaya, Omskaya Krasa, Pamyati Leont'yeva, Lyutescens 290/99-7, Lyutescens 89/06, Lyutescens 9/33, Lyutescens 259, Lyutescens 7/04-26, Chelyaba Yubilejnaya, Karagandinskaya 30, Lyutescens 1545, Stolypinskaya, Buryatskaya 55, Rodnik, Tibal't, Altajskaya 100, Altajskaya 105). In 2018, we examined 14 varieties (Tulajkovskaya 108, Celina 50, Dostyk, Sigma, Saratovskaya 75, Kinel'skaya Yubilejnaya, Tulajkovskaya Nadezhda, Sigma 2, Stolypinskaya, Buryatskaya 55, Rodnik, Tibal't, Altajskaya 100, Altajskaya 105). Sowing was carried out after cereal crop predecessor in the second decade of May. Plot size was 10 $\mathrm{m}^{2}$, seeding rate was $500 \mathrm{grains} / \mathrm{m}^{2}$. Canopy temperature was measured using a portable infrared thermometer (UT300C, Uni-Trend Group Limited, China) in the afternoon (12:00-15:00) during vegetative (2017) and grain filling (2018) stages. Unfortunately, it was not possible to avoid windy weather. Three measurements per plot were taken standing close to the plot (with the sun behind and avoiding shadows) and approximately $50 \mathrm{~cm}$ above the canopy with an angle $30^{\circ}$ from the horizontal. Measurements were taken in late booting stage (Zadoks 40-47) in 2017 and post-flowering stage (Zadoks 70-85) in 2018. Period from seeding to heading, spikes per square meter, plant height, spikelets per spike, kernels per spike, thousand kernel weight, grains weight per main spike, harvest index and grain yield have been studied. All measurements were performed using 10 plants of each sample. Weather conditions in 2017 and 2018 were generally favorable for plant growth and development. In 2017, hot weather and a deficit of precipitation were observed a week before heading; in 2018, these conditions were at the onset of milk ripeness.

Analysis of variance (ANOVA) of CTD measurements on each growth stage was carried. The reliability of the differences among the mean values of a pair of genotypes was tested using the Least Significant Differences $\left(\operatorname{LSD}_{0,05}\right)$. In addition, we calculated the correlation coefficients ( $r$ ) between the agronomic traits of genotypes and CTD, as well as the coefficient of variation ( $C_{v}$ ) of CTD. The statistical analyses were performed using the Microsoft Office Excel 2010 application software.

\section{Results}

Using data from 11 varieties present in the trial in both years, a two-way analysis of variance for CTD was calculated (Table 1).

Table 1. Analysis of variance of 11 varieties of spring soft wheat by Canopy temperature depression (CTD) in 2017 and 2018.

\begin{tabular}{llllll}
\hline Source of variation & SS & df & ms & $\mathbf{F}_{\text {fact }}$ & $\mathbf{F}_{\text {st. 0,05 }}$ \\
Year & 0,2 & 1 & 0,2 & 0,1 & 4,1 \\
Genotype & 24,9 & 10 & 2,5 & 1,0 & 2,1 \\
Genotype $\times$ Year Interaction & 20,9 & 10 & 2,1 & 0,8 & 2,1 \\
Error & 112,3 & 44 & 2,6 & - & - \\
\hline
\end{tabular}

The average CTD values for the varieties were approximately equal in both vegetations $\left(4.0^{\circ} \mathrm{C}\right.$ and $4.1^{\circ} \mathrm{C}$ in 2017 and 2018 , respectively). However, differences between genotypes were significant. In 2017, the group of varieties that most lowered the temperature of plants included Saratovskaya $70\left(5.1^{\circ} \mathrm{C}\right)$, Altajskaya $100\left(5.2^{\circ} \mathrm{C}\right)$, Sigma $\left(5.2^{\circ} \mathrm{C}\right)$, Sigma $2\left(5.2^{\circ} \mathrm{C}\right)$, Voevoda $\left(5.3^{\circ} \mathrm{C}\right)$. Altajskaya $105\left(3.8^{\circ} \mathrm{C}\right)$, Lyutescens $89 / 06\left(3.6^{\circ} \mathrm{C}\right)$, Karagandinskaya $30\left(3.6^{\circ} \mathrm{C}\right)$, Rodnik $\left(3.6^{\circ} \mathrm{C}\right)$, Stolypinskaya $\left(3.5^{\circ} \mathrm{C}\right), \mathrm{Tibal}^{\mathrm{t}}$ $\left(3.5^{\circ} \mathrm{C}\right)$, and Buryatskaya $55\left(2.7^{\circ} \mathrm{C}\right)$ were characterized by the smallest decrease in temperature. $\mathrm{LSD}_{05}$ value for genotypes studied in 2017 was $1.3^{\circ} \mathrm{C}$. In 2018 , Rodnik $\left(4.8^{\circ} \mathrm{C}\right)$ and Altajskaya $105\left(5.7^{\circ} \mathrm{C}\right)$ showed the highest values of Canopy temperature depression. The group with the lowest CTD values included Stolypinskaya $\left(3.1^{\circ} \mathrm{C}\right)$, Saratov $75\left(3.0^{\circ} \mathrm{C}\right)$, Tibal't $^{\prime}\left(2.8^{\circ} \mathrm{C}\right)$, Buryatskaya $^{\circ}$ $55\left(2.7^{\circ} \mathrm{C}\right)$, and Altajskaya $100\left(2.5^{\circ} \mathrm{C}\right)$. Differences between genotypes are also statistically significant $\left(\mathrm{LSD}_{05}=1.6^{\circ} \mathrm{C}\right)$.

According to our data, CTD refers to traits with medium and strong variation. So in 2017, $\mathrm{C}_{\mathrm{v}}$ ranged from 12 to $77 \%$ (an average of $39 \%$ ). In the growing season of 2018, this indicator changed between 10 and 54\% (an average of 25\%). In addition, in 2017, analysis of variance revealed a significant difference between blocks (replicates) at $p<0.01$. Correlation analysis has allowed us to establish the absence of a reliable interrelation between CTD and various agronomic traits of varieties, including yield (Table 2). Plant height in 2018 was the only trait that showed a positive reliable correlation with CTD $(r=0.83)$. The medium correlation according to the values, but nevertheless statistically insignificant, was noted between CTD and yield in 2017 ( $r=0.31)$ as well as between CTD and spikes per square meter, spikelets per spike, thousand kernel weight and harvest index in 2018 ( $r=0.33$; 0.39 ; $0.36 ;-0.33$ respectively).

Table 2. Simple correlation coefficients of Canopy temperature depression (CTD) with agronomic traits of spring soft wheat varieties in 2017 and 2018.

\begin{tabular}{lll}
\hline Agronomical traits & Growing season & \\
& $\mathbf{2 0 1 7}$ & $\mathbf{2 0 1 8}$ \\
Period from seeding to heading & -0.02 & 0.31 \\
Spikes per square meter & 0.10 & 0.33 \\
Plant height & 0.29 & $\mathbf{0 . 8 3}$ \\
Spikelets per spike & -0.09 & 0.39 \\
Kernels per spike & 0.16 & -0.29 \\
Thousand kernel weight & 0.13 & 0.36 \\
\hline
\end{tabular}




\begin{tabular}{lll}
\hline Grains weight per main spike & & \\
Harvest index & 0.17 & -0.05 \\
Grain yield & 0.10 & -0.33 \\
$r_{\text {table } 0.05}$ & 0.31 & -0.14 \\
\hline
\end{tabular}

\section{Discussion}

The revealed statistically significant differences in CTD between the genotypes both in 2017 and 2018 indicate that among the Russian varieties of spring soft wheat that we studied there is a diversity on this trait. We are inclined to attribute high coefficients of variation ( $25 \%$ and $39 \%$ ) for CTD both to the measurement features of this trait and to the conditions of the experiment. This is not surprising, as CTD is measured on a plot basis, unlike other traits, which are measured on individual plants, thus increasing experimental error since fewer plants are incorporated into an average reading (Reynolds et al., 1998). In 2017, during the temperature measurement, there was no complete closure of the canopy, and the upper layer of the leaves was close to the soil surface. As a result, higher soil temperatures served as a source of additional variation in CTD measurements.

Numerous studies carried out in various countries have established diversity among wheat genotypes in Canopy temperature depression (Balota et al., 2007; Karimizadeh and Mohammadi, 2011; Khan et al., 2014; Ray and Ahmed, 2015; Jangid and Srivastava, 2018). The significant and positive correlation of CTD with five drought tolerance indices and yield of durum wheat in the rainfed and supplementary irrigation conditions was established (Karimizadeh and Mohammadi, 2011). Bahar et al. (2008) showed that Canopy temperature depression of bread wheat was positively correlated with grain yield, spike yield, and grain numbers per spike in heat and drought stress conditions. Guendouz et al. (2012) found that under dryland conditions, grain yield and mean CTD were correlated positively, but under irrigated condition CTD correlated negatively with grain yield. Yıldırım et al. (2013) found positive correlations of the trait with grain yield under non-stress conditions. Our study did not establish a reliable correlation between CTD and yield. Similar results were obtained from researchers who indicated a weak relationship between CTD and yield under favorable conditions (Olivares-Villegas et al., 2007).

A significant correlation between CTD and plant height indicates that tall plants have better ability to cool and bring the temperature to a more optimal values for photosynthesis. This probably explains the fact that tall wheat varieties are still cultivated in Siberia and Northern Kazakhstan. Together with the short stalk determined by one of the Rht genes (Rht 2), spring soft wheat plants become less adapted to growing conditions in Western Siberia (Lichenko and Lichenko, 2009). Lopes et al. (2012), as well as Mason and Singh (2014), showed a strong negative correlation $(r=-0.64)$ between plant height and Canopy temperature under drought. Genetic mapping shows CT to be controlled mostly by small effect loci that are pleiotropic with variation in plant height (Pinto et al., 2010; Rebetzke et al., 2013).

CTD measurement requires suitable weather (Olivares-Villegas et al., 2007), which is not always possible in Siberia. Significant variation of this feature requires repeated measurements, which slows down the measurement speed of CTD and deprives it of the main advantage over other methods, that is, speed. Although the method of infrared thermometry allows us to differentiate genotypes into groups, we cannot pay attention to the change in the rank of genotypes based on CTD in Altajskaya 100, Altajskaya 105 and Rodnik. Thus, the stability of the manifestation of the trait in various conditions is not realized, which is one of the most important requirements for the selection criterion (Lonbani and Arzani, 2011). Nevertheless, the essential advantages of this method include its objectivity and ability to keep plants alive. However, in practical breeding, the applicability of the method is limited to generations, when the breeder has enough seeds for sowing on large plots. It is obvious that CTD has the potential to help breeders in early generations to identify those populations that later will give the highest yielding lines (Reynolds et al., 2001; Van Ginkel et al., 2004). If the Siberian drought occurs before heading, when the plants are so oppressed that they do not tiller and close the canopy, the use of infrared thermometry does not have any prospects throughout the growing season. In Siberia, this method is suitable only under conditions of mild droughts or when sowing wheat using a steam precursor.

\section{Conclusion}

We established significant differences for CTD values between the varieties of spring soft wheat when growing in the Altai Territory of Russia. CTD did not significantly correlate with grain yield in neither 2017 nor 2018 ( $r=0.31 ; r=-0.14)$. However, we found a correlation of the trait with the plant height in $2018(r=0.83)$. This may explain the wide distribution of tall varieties in Siberia. If drought occurs before heading, when the plants are oppressed and do not close the canopy, the use of infrared thermometry is difficult throughout the growing season. We believe that in Siberia this method is suitable only in the conditions of mild droughts or when using the steam precursor in wheat cultivation.

\section{Conflict of Interest}

The authors declare that they have no conflict of interests.

\section{References}

Amani, I., Fischer, R. A., \& Reynolds, M. P. (1996). Canopy temperature depression associated with yield of irrigated spring wheat cultivars in a hot climate. J Agron Crop Sci, 176, 119-129.

Araus, J. L., Slafer, G. A., Reynolds, M. P., \& Royo, C. (2002). Plant breeding and drought in C3 cereals: what should we breed for? Annals of Botany, 89, 925-940. doi: 10.1093/aob/mcf049

Bahar, B., Yildirim, M., Barutcular, C., \& Genc, I. (2008). Effect of canopy temperature depression on grain yield and yield components in bread and durum wheat. Not. Bot. Hort. Agrobot. Cluj, 36 (1), 34-37.

Bala, P., \& Sikder, S. (2018). Impact of post-anthesis heat stress on physiological and biochemical traits of wheat genotypes. Journal of Stress Physiology \& Biochemistry, 14, 3, 27-37.

Balota, M., Payne, W. A., Evett, S. R., \& Lazar, M. D. (2007). Canopy temperature depression sampling to assess grain yield and genotypic differentiation in winter wheat. Crop Science, 47, 1518-1529. doi: 10.2135/cropsci2006.06.0383

Guendouz, A., Guessoum, S., Maamri, K., Benidir, M., \& Hafsi, M. (2012). Canopy temperature efficiency as indicators for drought tolerance in durum wheat (Triticum durum Desf.) in semi arid conditions. Journal of Agriculture and Sustainability, 1, 1, 23-38.

Jangid, K. K., \& Srivastava, J. P. (2018). Canopy temperature depression and stay green: major components for identifying terminal heat stress resistant genotypes of wheat. Int. J. Pure App. Biosci., 6(3), 374-381. doi: http://dx.doi.org/10.18782/2320-7051.6691 
Karimizadeh, R., \& Mohammadi, M. (2011). Association of canopy temperature depression with yield of durum wheat genotypes under supplementary irrigated and rainfed conditions. AJCS, 5(2), 138-146.

Khan, A. A., Shamsuddin, A. K. M., Barma, N. C. D., Alam, M. K., \& Alam M. A. (2014). Screening for heat tolerance in spring wheat (Triticum aestivum L.). Tropical Agricultural Research \& Extension, 17(1), 2014, 26-37.

Kumakov, V. A. (1986). Physiological approaches to plant breeding for productivity and drought tolerance. Agricultural Biology, 6, 27-34. (In Russian)

Lepekhov, S. B., \& Korobeynikov, N. I. (2013). Field and agronomic drought resistance of soft wheat varieties in forest-steppe conditions of the Altai Region. Bulletin of Altai State Agricultural University, 1(99), 9-12. (In Russian)

Lepekhov, S.B., Khlebova, L.P. (2018). Assessment of drought resistance indices in spring bread wheat under various environmental conditions. Ukrainian Journal of Ecology, 8(4), 314-319

Lichenko, I. E., \& Lichenko, N. N. (2009). Negative effects of some genes (traits) of soft wheat. Siberian Herald of Agricultural Science, 5(197), 27-33. (In Russian)

Lonbani, M., \& Arzani, A. (2011). Morpho-physiological traits associated with terminal drought stress tolerance in triticale and wheat. Agronomy Research, 9, 315-329.

Lopes, M. S., Reynolds, M. P., Manes, Y., Singh, R. P., Crossa, J., \& Braun, H. J. (2012). Genetic yield gains and changes in associated traits of Cimmyt spring bread wheat in a "historic" set representing 30 years of breeding. Crop Sci., 52, $1123-1131$.

Mason, R. E., \& Singh, R. P. (2014). Considerations when deploying canopy temperature to select high yielding wheat breeding lines under drought and heat stress. Agronomy, 4, 191-201. doi:10.3390/agronomy4020191

Montes, J. M., Melchinger, A. E., \& Reif, J. C. (2007). Novel throughput phenotyping platforms in plant genetic studies. Trends Plant Sci, $12,433-436$.

Morgounov, A., \& Trethowan, R. (2008). Avenues to increase yield potential of short season, high latitude wheat in Northern Kazakhstan and Siberia. Reynolds, M. P., J. Pietragalla, H.-J. Braun (eds). International symposium on wheat yield potential: Challenges to international wheat breeding. CIMMYT, Mexico, D.F.

Olivares-Villega, J. J., Reynolds, M. P., \& McDonald, G. K. (2007). Drought-adaptive attributes in the Seri/Babax hexaploid wheat population. Functional Plant Biology, 34, 189-203. doi 10.1071/FP06148

Pinto, R. S., Reynolds, M. P., Mathews, K. L., McIntyre, C. L., Olivares-Villegas, J. J., \& Chapman, S. C. (2010). Heat and drought adaptive QTL in a wheat population designed to minimize confounding agronomic effects. Theor Appl Genet, 121, 1001-1021. DOI $10.1007 / \mathrm{s} 00122-010-1351-4$

Ray, J., \& Ahmed J. U. (2015). Canopy temperature effects on yield and grain growth of different wheat genotypes. Journal of Agriculture and Veterinary Science, 8, 7 48-55.

Rebetzke, G. J., Rattey, A. R., Farquhar, G. D., Richards, R. A., \& Condon, A. G. (2013). Genomic regions for canopy temperature and their genetic association with stomatal conductance and grain yield in wheat. Funct. Plant Biol., 40, 14-33.

Reynolds, M. P., Nagarajan S., Razzaque M. A., \& Ageeb, O. A. A. (2001). Breeding for adaptation to environmental factors, heat tolerance. Reynolds, M. P., J. I. Ortiz-Monasterio, A. McNab (eds). Application of physiology in wheat breeding, CIMMYT, Mexico, DF.

Reynolds, M. P., Singh, R. P., Ibrahim, A., Ageeb, O. A. A., Larque'-Saavedra, A., \& Quick, J. S. (1998). Evaluating physiological traits to complement empirical selection for wheat in warm environments. Euphytica, 100, 85-94.

Van Ginkel, M., Reynolds, M., Trethowan, R., \& Hernandez, E. (2004). Can canopy temperature depression measurements help breeders in selecting for yield in wheat under irrigated production conditions? Proceedings of the 4th International Crop Science Congress, Brisbane, Australia, 26 September-1 October, 2004. Available online at http://www.cropscience.org.au/ icsc2004/poster/3/4/6/1353_vanginkelm.htm (verified 8/ 11/05).

Winslow, M. D., \& Smirnoff, N. (1984). Physiological techniques used to screen breeders nurseries for drought resistance. Rachis, 3 , 2, 44-46.

Yıldırım, M., Koç, M., Akıncı, C., \& Barutçular, C. (2013). Variations in morphological and physiological traits of bread wheat diallel crosses under timely and late sowing conditions. Field Crops Research, 40, 9-17.

\section{Citation:}

S.B. Lepekhov, L.P. Khlebova (2019). Association of canopy temperature depression with yield and morphological traits of spring soft wheat under Siberian conditions. Ukrainian Journal of Ecology, 9(3), 389-392.

(cc)) BY This work is licensed under a Creative Commons Attribution 4.0. License 